\title{
Citizenship Deprivation, Security and Human Rights
}

\author{
Lucia Zedner* \\ Professor, Faculty of Law, University of Oxford and \\ Conjoint Professor, Faculty of Law, UNSW, Sydney
}

\begin{abstract}
In response to the rise of IS and the growing problem of foreign fighters, deprivation of citizenship of persons deemed to threaten the interests of the state has been revived as a key tool for security and counterterrorism. Yet, citizenship deprivation raises profound issues for human rights. In the UK, the Immigration Act 2014 includes a power to deprive naturalized British citizens of their citizenship on security grounds, even if doing so would render individuals stateless. The UK government has argued that deprivation would satisfy the requirements of necessity and proportionality under Article $8(2)$ ECHR, provided it could be shown to be necessary in a democratic society in the interests of national security, public safety or the economic well-being of the UK. Yet the risks are not only to private and family life. Citizenship deprivation may also involve other rights (not least Articles 2 and 3) where the consequence of deprivation is that individuals suffer loss of life, torture, inhuman or degrading treatment or punishment. This article explores the genesis of citizenship deprivation resulting in stateless and offers a strong critique on grounds of legality and rights. It also raises serious questions about its efficacy as a security strategy.
\end{abstract}

\section{Keywords}

Counterterrorism; deportation; citizenship deprivation; denaturalization; statelessness

\section{Introduction}

Since the rise of the Islamic State (IS), the war in Syria and Iraq has attracted more foreign fighters who join or seek to join IS than any other past or present conflict. Of the estimated 20,000 foreign combatants in Syria and Iraq, an estimated 3,850 fighters come from Europe. ${ }^{1}$ The gravity of the threats posed by the rise of the Islamic State to the stability of the Middle East and to the security of those nations from which foreign fighters are recruited should not be underestimated. ${ }^{2}$ The Director of Europe's law

\footnotetext{
${ }^{*}$ E-mail: lucia.zedner@law.ox.ac.uk. I am grateful to Alessandro Spena, Luisa Marin, Mary Bosworth and Matthew Gibney for their comments and suggestions and to Cian Ó Concubhair for his research assistance.

1) European Parliament Briefing 'Foreign Fighters': Member States' responses and EU action in an international context. (European Parliamentary Research Service 2015). http://www.europarl.europa.eu/EPRS/EPRS-Briefing-548980-Foreign-fighters-FINAL.pdf.

${ }^{2)}$ P. Cockburn (2015) The Rise of Islamic State: Isis and the New Sunni Revolution, New York: Verso.
} 
enforcement agency Europol, Rob Wainwright, has warned that IS poses 'the most serious terrorist threat Europe has faced since 9/11'. ${ }^{3}$ Accordingly, he has cautioned that ' $[t]$ he reality is today the security authorities don't have the necessary capability ... to fully protect society from these kind of threats'. ${ }^{4}$ Like Wainwright, security chiefs across Europe warn of a 'capability gap' in the power of national security services to deal with the threat posed. ${ }^{5}$

Some estimates suggest that the number of Europeans who have travelled to the Middle East in order to fight for the Islamic State (IS) doubled in 2014 alone. There is considerable variation by state: for example, the number of French fighters nearly trebled to 1,200 in $2014 .{ }^{6}$ In early 2015, 600 Britons, who had travelled to Iraq and Syria since the start of the conflict, were identified as 'individuals of interest' to the security services. ${ }^{7}$ Those sufficiently radicalized to join IS are an urgent problem for governments, not least because if these fighters return home they pose a potentially serious threat to national security. For example, the shooting at the Jewish Museum in Brussels in 2014 was perpetrated by a man believed to have spent over a year in Syria, those involved in the Charlie Hebdo attack in Paris in January 2015 reportedly trained in Yemen, and one of the suicide bombers at Bataclan in Paris in November 2015 was suspected of having travelled to Syria in 2013 to fight for IS. ${ }^{8}$

The external borders of the European Union have been strengthened by extensive systems of control: the formation of transnational surveillance systems such as Eurosur (European Border Surveillance System); requirements to collect and share data (eg, using Eurodac, a database of the fingerprints of asylum seekers); and the establishment of the European border policing agency Frontex..$^{9}$ Co-operative international policing arrangements under the Schengen Agreement (1995) offset the relaxation of border controls between signatory states by increased use of profiling, surveillance, and checks on those deemed to pose a risk. ${ }^{10}$ Member states export some controls to the borders of the European Union and beyond, for example, through the screening of air passengers before boarding and the detention of undocumented migrants at the point of departure. ${ }^{11}$ Such arrangements target the movement of those deemed to threaten security both at the geographical border of the nation state and, increasingly,

\footnotetext{
3) M. Holden (2015) 'Up to 5,000 European fighters in Syria pose risk: Europol', Reuters 13.01, http://www.reuters.com/article/2015/01/13/us-france-shooting-europol-idUSKBN0KM1YC20150113.

4) Ibid.

5) For a critical analysis see D. Bigo et al. (2015) The EU Counter-Terrorism Policy Responses to the Attacks in Paris: Towards an EU Security and Liberty Agenda No. 81, CEPS Paper in Liberty and Security in Europe, Brussels: CEPS.

6) C. Harris (2015) 'Big rise in European fighters in Iraq and Syria', euronews 29.01, http://www.euronews.com/2015/01/29/european-fighters-in-iraq-and-syria-double-in-a-year/.

7) Ibid.

8) http://www.huffingtonpost.com/2015/01/11/charlie-hebdo-gunmen_n_6451600.html; http://www.telegraph.co.uk/news/worldnews/europe/france/11996120/Paris-attack-what-weknow-about-the-suspects.html.

${ }^{9)}$ KF. Aas (2011). "Crimmigrant” Bodies and Bona Fide Travelers: Surveillance, Citizenship and Global Governance', Theoretical Criminology, 15(3), pp. 331-346 at 333.

10) Ibid. pp. 337-8.

11) KF. Aas (2012). '(In)Security-at-a-Distance: Rescaling Justice, Risk and Warfare in a Transnational Age', Global Crime, 13(4), pp. 235-53.
} 
well beyond it. ${ }^{12}$ However, as the terrorist attacks in Paris in November 2015 made clear, it is all too easy for would-be terrorists to cross borders within Europe unchallenged.

Across Europe, states are under pressure to take measures to disrupt and disable terrorist networks, associations and activities in order to prevent further attacks. The EU has sought to co-ordinate Member State activities with regard to the prevention of radicalisation, ${ }^{13}$ detection and prevention of suspicious travel, and monitoring devices such as Passenger Name Records (PNR). ${ }^{14}$ Supra-national security arrangements only partially decouple security from the territory of the nation state and its right to control its own border. The primary responsibility for national security and counter-terrorism remains at state level. Member states most affected by the radicalization of citizens have taken significant steps to prevent extremism and to deal with suspected terrorists or would-be jihadi fighters through counterterorrism as well as criminal law. ${ }^{15}$ Increasingly, states also have recourse to immigration law as a tool of counterterrorism to limit mobility and to secure borders. ${ }^{16}$

This article examines a particularly troubling instance of resort to immigration law as a tool of counterterrorism - citizenship deprivation. Its focus is a recent legislative development under the UK Immigration Act 2014 that permits the denaturalization of naturalized British citizens who are deemed to have conducted themselves 'in manner which is seriously prejudicial to the vital interests of the United Kingdom', even where so doing risks rendering individuals stateless. The article examines the legal and rightsbased objections to this provision and questions its claim to be an effective weapon against terrorism.

\footnotetext{
12) KF. Aas \& M. Bosworth (eds.) (2013) The Borders of Punishment: Criminal justice, citizenship and social exclusion, Oxford: Oxford University Press, ch. $1 \& 5$.

${ }^{13)}$ Council of the European Union (2014) Revised EU Strategy for Combating Radicalisation and Recruitment to Terrorism, Brussels: Council of the European Union data.consilium.europa.eu/doc/document/ST-9956-2014-INIT/en/pdf.

${ }^{14)} \mathrm{http} / / / \mathrm{www}$.europarl.europa.eu/oeil/popups/ficheprocedure.do?lang=\&reference $=2011 / 0023 \%$ $28 \mathrm{COD} \% 29$.

${ }^{15)}$ A. Aliverti (2013) Crimes of Mobility: Criminal Law and the Regulation of Immigration, Abingdon, UK: Routledge; L. Zedner (2014) 'Terrorizing Criminal Law', Criminal Law and Philosophy 8(1), pp. 99-121. On the UK's counter-extremism strategy see

https://www.gov.uk/government/publications/counter-extremism-strategy.

16) N. Demleitner (2004) 'Misguided Prevention: The War on Terrorism as a War on Immigrant Offenders and Immigration Violators', Criminal Law Bulletin, 40, pp. 550-75; J. Huysmans \& A. Buonfino (2008) 'Politics of Exception and Unease: Immigration, Asylum and Terrorism in Parliamentary Debates in the UK', Political Studies, 56(4), pp. 766-88; T. Miller (2005) 'Blurring the Boundaries between Immigration and Crime Control after September 11th', Boston College Third World Law Journal, 25, pp. 81-124.
} 


\section{Resort to Immigration Law as Counterterrorism}

Reliance upon immigration law as a security strategy grew significantly after the terrorist attacks of 9/11 in the USA, and the Bali, Madrid and London bombings. ${ }^{17}$ This development reflects the broader securitization of immigration and the linking of immigration control with counterterrorism in public debate. ${ }^{18}$ Evidence that security lapses at the border played some part in the 9/11 attacks also prompted readier identification of tight immigration control as vital to national security. ${ }^{19}$ Terrorist suspects and perpetrators were identified as outsiders: within weeks of the 9/11 attacks, the then UK Prime Minister, Tony Blair, announced plans to 'increase our ability to exclude and remove those whom we suspect of terrorism and who are seeking to abuse our asylum procedures'. ${ }^{20}$ Perhaps this should not surprise. Macklin observes the 'emotive power of invoking the spectre of the foreigner as an intrinsic menace to national security'. ${ }^{21}$ Resort to immigration law derives in part from a tendency to cast foreigners and aliens as a threat to social order. It derives also from the impulse to combat terrorism by any available legal means. ${ }^{22}$ In this context, immigration law is considered a potentially valuable weapon in the counterterrorism armory.

Some EU Member States, for example Denmark, France, Germany, the Netherlands and the UK, have long had legal powers to confiscate the passports or travel documents of those deemed to pose a security risk. Other provisions to limit mobility on security grounds include revocation of residence permits, travel bans, and prohibition from entering or leaving a country; such that, as Chacón observes, 'the border has become the front line in the fight against terrorism'. ${ }^{23}$ Immigration law as a means of controlling serious crime and terrorism is attractive to governments because, in setting weaker procedural protections and lower standards of proof, it is regarded as more reliable and

\footnotetext{
17) Notwithstanding the fact that only one of the four perpetrators of the London $7 / 7$ bombings, Germaine Lindsay, was born outside the UK. Jamaican-born Lindsay had lived in Britain since the age of 5 .

18) A. Dobrowolsky (2007) '(In)Security and Citizenship: Security, Im/migration and Shrinking Citizenship Regimes', Theoretical Inquiries in Law, 8(2), pp. 628-662, at 660.

19) Macklin observes, 'there seems little doubt that the utter inadequacy of security check in airports across North America contributed to the outcome of September 11'. A. Macklin (2001) 'Borderline Security', in: R.J. Daniels, P. Macklem \& K. Roach (eds.), The Security of Freedom, Toronto: University of Toronto Press, pp. 383-404, at 383.

20) 'Full text of Tony Blair's speech to parliament', The Guardian, 4 October 2001, http://www.theguardian.com/world/2001/oct/04/september11.usa3.

21) A. Macklin (2001) 'Borderline Security', in: R.J. Daniels, P. Macklem \& K. Roach (eds.), The Security of Freedom, Toronto: University of Toronto Press, pp. 383-404, at 384. See also J. Huysmans (2006) The Politics of Insecurity: Fear, Migration and Asylum in the EU, London: Routledge, ch. 4; R.C. Mawby \& W. Gisby (2009) 'Crime Fears in an Expanding European Union: Just Another Moral Panic?', The Howard Journal of Criminal Justice, 48(1), pp. 37-51; A. Ashworth \& L. Zedner (2014) Preventive Justice, Oxford: Oxford University Press, pp. 225-228.

${ }^{22)}$ S. Krasmann (2007) 'The Enemy on the Border: Critique of a Programme in Favour of a Preventive State', Punishment and Society 9(3), pp. 301-318; C. Gomez-Jara Diez (2008) 'Enemy combatants versus enemy criminal law', New Criminal Law Review 11(4), pp. 529-562.

23) J.M. Chacón (2007) 'Unsecured Borders: Immigration Restrictions, Crime Control and National Security', Connecticut Law Review, 39, pp. 1827-1891; N. Demleitner (2004) 'Misguided Prevention: The War on Terrorism as a War on Immigrant Offenders and Immigration Violators', Criminal Law Bulletin 40, pp. 550-575.
} 
effective than the slow, expensive and uncertain passage of the criminal process. ${ }^{24}$ It permits the state to impose draconian measures upon suspected terrorists without the legal hurdles of evidence and high standards of proof that are intrinsic to the criminal process. In the UK, the use of secret evidence in closed material proceedings (CMP) by the Special Immigration Appeals Commission (SIAC) protects security sensitive intelligence but denies subjects the basic right to know the full details of the case against them. ${ }^{25}$ This facility for hearing proceedings behind closed doors may enable the government to maintain the secrecy of intelligence, informants, operatives and operations but it does so only at the cost of radically eroding the ability of subjects to contest their case. ${ }^{26}$

Alongside and at the same time as resort to immigration law for counterterrorism purposes, criminal and counterterrorism laws are increasingly used to control mobility across borders. For example, in the UK, Travel Restriction Orders introduced under the Criminal Justice and Police Act 2001 s. 33 severely restrict the movement of those deemed to pose a risk. More recently, the UK's Counterterrorism and Security Act (CTSA) 2015 included provisions that curtail mobility in order to disrupt travel to 'locations which facilitate terrorist networking, training, and experiences which provide individuals with enhanced capabilities on their return'. ${ }^{27}$ Section 1 of CTSA 2015 permits the police to seize the travel documents of those suspected of intending to leave Great Britain in connection with terrorism-related activity and to retain these documents for up to 14 days. There is no judicial oversight of the exercise of this power unless the police wish to retain the passport beyond 14 days, at which point they must seek judicial authority for renewal, which may be granted for up to 30 days from the day after the passport was first seized. As such, this new power constitutes a significant extension of existing prerogative powers to refuse to issue or to cancel a passport on public interest grounds.

Section 2 of CTSA 2015 enacts a Temporary Exclusion Order (TEO) that may be imposed where a number of specified conditions are met, most importantly that the Home Secretary 'reasonably suspects that the individual is, or has been, involved in terrorism-related activity outside the United Kingdom' and 'reasonably considers that it is necessary, for purposes connected with protecting members of the public in the United Kingdom from a risk of terrorism'. ${ }^{28}$ The TEO prevents a suspect individual

\footnotetext{
${ }^{24)}$ M. Bosworth \& M. Guild (2008) 'Governing Through Migration Control: Security and Citizenship in Britain', British Journal of Criminology 48(6), pp. 703-719; L. Zedner (2010) 'Security, the State, and the Citizen: The Changing Architecture of Crime Control', New Criminal Law Review 13, pp. 379-403.

25) Justice (2009) Secret Evidence, London: Justice; A. Kavanagh (2010) 'Special Advocates, Control Orders and the Right to a Fair Trial', Modern Law Review 63(5), pp. 836-857. The minimum requirements of disclosure are set out in Secretary of State for the Home Department $v$ AF and others [2009] UKHL 28.

26) J. Ip (2012) 'Al Rawi, Tariq, and the Future of Closed Material Procedures and Special Advocates', Modern Law Review, 75(4), pp. 606-623.

27) Home Office (2014) Counterterrorism and Security Bill - Temporary Passport Seizure. Impact Assessment, London, p. 8, 18.11.2014, http://www.parliament.uk/documents/impact-assessments/IA14-22F.pdf.

28) Ibid.
} 
from returning to the UK for two years and it is renewable indefinitely under s. 4(8). ${ }^{29}$ For those stranded overseas, the TEO may be extremely difficult to challenge. The motivating idea behind these orders appears to be that powers to limit mobility and prevent would-be terrorists from travelling abroad or returning home will help to prevent or, at least, to inhibit terrorism.

Although the UK provisions go much further than most, Britain is certainly not alone in seeking to limit the mobility of those deemed to pose a security threat. Denmark, for example, has enacted powers to confiscate the passports of minors; in both the Netherlands and Belgium minors can be coercively prevented from leaving the country and placed in protective custody; in the Netherlands it is also possible to rescind the residency permit of non-nationals and to strip dual nationals of their Dutch citizenship on national security grounds; and Germany has a travel disruption strategy to prevent aspiring foreign fighters from leaving the country and has the power to confiscate the passport of German (but not non-German) citizens. ${ }^{30}$

\section{Citizenship Deprivation}

Deprivation of citizenship is among the harshest of all these disruptive measures in that it places the individual outside the protections bestowed by virtue of membership of a state. ${ }^{31}$ For citizens of European Member States, it may result in the additional loss of all the rights and advantages that adhere to European citizenship. Although the European Court of Justice has accepted that deprivation is a matter of state sovereignty, in Rottman it paved the way for possible incursions by determining that potential loss of EU citizenship is sufficiently grave for the Court to consider the legitimacy of a decision by applying the test of proportionality. ${ }^{32}$

Citizenship deprivation has long been widely used to target those deemed to threaten national security. ${ }^{33}$ In the UK, on the outbreak of the First World War, the British Nationality and Status of Aliens Act 1914 provided for revocation of naturalized citizenship on a number of grounds, including fraud and misrepresentation. The British National and Status of Aliens Act 1918 further extended the grounds for denaturalization but in practice these powers were only rarely used. ${ }^{34}$ Resort to citizenship

\footnotetext{
29) http://www.legislation.gov.uk/ukpga/2015/6/part/1/enacted.

${ }^{30)}$ Center for Security Studies (2014) Foreign Fighters: An Overview of Responses in Eleven Countries, Zurich: ETH, http://www.css.ethz.ch/publications/DetailansichtPubDB_EN?rec_id=2998.

${ }^{31)}$ R. Bauböck \& S. Paskalev (2015) Citizenship Deprivation: A Normative Analysis, CEPS Paper in Liberty and Security in Europe 82, pp. 1-37, http://www.ceps.eu/publications/citizenship-deprivation-normative-analysis.

32) Case C-135/08 Rottmann v Freistaat Bayern, 2 March 2010. For further discussion see http://eudo-citizenship.eu/commentaries/citizenship-forum/citizenship-forum-cat/254-has-the-european-court-of-justice-challenged-member-state-sovereignty-in-nationality-law?showall=\&limitstart=; A. Berry (2014) 'Deprivation of Nationality and Citizenship - The Role of EU Law', Immigration, Asylum and Nationality Law 28(4), pp. 355-366.

${ }^{33)}$ S. Lavi (2010) 'Punishment and the Revocation of Citizenship in the United Kingdom, United States, and Israel', New Criminal Law Review 13(2), pp. 404-426, at 409-413.

34) M. Gibney (2014) 'The Deprivation of Citizenship in the United Kingdom: A Brief History', Journal of Immigration Asylum and Nationality Law 28(4), pp. 326-335, at 327-328.
} 
stripping was revived under the British Nationality Act 1981 s. 40, which provided for denaturalization if an individual was sentenced to prison for at least 12 months during the first five years of naturalization, unless deprivation would render the individual stateless. The 1981 Act was subsequently amended by the Nationality, Immigration and Asylum Act 2002, which provided for deprivation of citizenship only where it had been acquired fraudulently or where the Secretary of State was satisfied that the individual had conducted themselves in a manner that was 'seriously prejudicial to the vital interests' of the UK. However, s. 54 of the UK Immigration, Asylum and Nationality Act 2006 strengthened powers of removal and deportation to permit denial of refugee status to those who were found to have engaged in '(a) acts of committing, preparing or instigating terrorism and (b) acts of encouraging or inducing others to commit, prepare or instigate terrorism'. ${ }^{35}$ The 2006 Act also included a very much more wide-ranging power to "deprive a person of citizenship status if the Secretary of State is satisfied that deprivation is conducive to the public good"36 - a test that has rightly been the subject of considerable criticism. ${ }^{37}$ Yet judicial scrutiny of these provisions is weakened by the tendency of judges to defer to the executive in respect of decisions relating to national security.

Citizenship deprivation entails a very significant erosion of rights. Where it results in deportation, individuals may find themselves stranded in a country with which they may have little personal history, relation or sense of belonging. ${ }^{38}$ Deportation has serious implications also for human rights, not least the right to life under Article 2, to freedom from inhuman or degrading treatment or punishment under Article 3, and to private and family life under Article $8 \mathrm{ECHR}$, for those who find themselves cut off from family and dependents as a consequence. ${ }^{39}$

The UK government claims that it 'has shown itself to be committed to deport foreign nationals involved in terrorist activities in this country fully respecting our human rights obligations' ${ }^{40}$ In order to do so, it may seek to enter into a Memorandum of

${ }^{35)}$ M.J. Gibney (2013) 'Deportation, Crime and the Changing Character of Membership in the UK', in: K.F. Aas \& M. Bosworth (eds.), The Borders of Punishment, Oxford: Oxford University Press.

36) S. 56 Immigration, Asylum and Nationality Act 2006.

37) M. Gibney (2014) 'The Deprivation of Citizenship in the United Kingdom: A Brief History', Journal of Immigration Asylum and Nationality Law 28(4), pp. 326-335, at 232-233.

38) The growing trend in Europe and North America toward resort to denationalization has been the subject of lively debate. See e.g. the important debate by A. Macklin \& R. Bauböck (2015) The Return of Banishment: Do the New Denationalisation Policies Weaken Citizenship?, Robert Schuman Centre for Advanced Studies Research Paper No. RSCAS 2015/14 (available at SSRN: http://ssrn.com/abstract=2563555 or http://dx.doi.org/10.2139/ssrn.2563555 ), and responses on the EUDO on Citizenship Forum on Citizenship. See e.g. http://eudo-citizenship.eu/commentaries/citizenship-forum/1268-the-return-of-banishment-do-the-new-denationalisation-policies-weaken-citizenship.

See also E. Fripp (2014) 'Deprivation of nationality and public international law - an outline', Journal of Immigration, Asylum and Nationality Law 28(4), pp. 367-384.

${ }^{39)}$ A. Macklin (2014) 'Citizenship Revocation, the Privilege to Have Rights and the Production of the Alien', Queen's Law Journal 40, pp. 11-54.

${ }^{40)}$ HM Government (2011) Review of Counterterrorism and Security Powers Review Findings and Recommendations Cm., 8004, London, pp. 5-6, https://www.gov.uk/government/...data/.../reviewfindings-and-rec.pdf. 
Understanding (MoU) with a receiving country to ensure that a deportee is not subjected to violations under Article 3. Although an MoU secures formal assurances from the receiving state to ensure that deportation complies with human rights norms, it is questionable whether assurances from countries with poor human rights records, such as Algeria, Libya and Jordan, are reliable. Such countries may also be unable to satisfy the absolute prohibition on torture under the ECHR. Lacking the knowledge or expertise to determine the nature and extent of human rights abuses in receiving countries, courts are prone to defer to the executive and may accept such agreements at face value. ${ }^{41}$ In the high profile case of Abu Qatada (the Jordanian preacher, Omar Othman), the Strasbourg Court was eventually satisfied that the MoU would avert violation of Article 3, ECHR. ${ }^{42}$ However, it found that the applicant's right to a fair trial in the receiving country was not assured, since evidence obtained by torture was admissible in Jordan. Only when the MoU was extended to exclude this possibility was Britain able to deport Abu Qatada to Jordan in July 2013. Unhappily, by no means all cases are so high profile or subject to such robust judicial scrutiny.

In recent years, resort to citizenship deprivation and deportation by the UK government has increased very rapidly. Whereas in the 30 years to 2002 , only one person was deprived of his citizenship and between 2002-2006 just one more person was deprived (and that case was subject to challenge), ${ }^{43}$ from 2006 to March 2014, there were 41 deprivations, 27 of which were justified on grounds that it was conducive to the public good. ${ }^{44}$ Between 2013 and 2014 alone, 37 people had their citizenship rescinded. All were also citizens of other countries and the UK government was careful to point out that 'all were considered to have another alternative nationality' ${ }^{45}$ The strong inhibition against citizenship deprivation resulting in statelessness derives from recognition that it has the effect of withdrawing all the protections of nationality and leaves the individual at serious risk of human rights violations. It is to this issue that we now turn.

\section{The Commitment to Reducing Statelessness}

The Universal Declaration of Human Rights (1948) provides at Article 15 that 'everyone has the right to a nationality ... no one shall be arbitrarily deprived of his nationality'. The UK was a signatory to this provision as well as to the later UN Conventions on Statelessness (of 1954 and 1961). ${ }^{46}$ Significantly, however, the UK entered a reservation permitted under Art. 8(3)(a) of the 1961 Convention to retain 'the right to deprive a naturalized person of his nationality' and render them stateless in specific

\footnotetext{
41) See for example, RB (Algeria) $v$ Secretary of State, UKHL, 20 (2009).

42) The case was known as Othman v United Kingdom (2012) 55 EHRR 1; for a different and unsuccessful attempt at a satisfactory MoU, the UK government intervening, see Saadi v Italy (2008) 49 EHRR 730.

43) Immigration Law Practitioners' Association (ILPA) (2014) Information Sheet Deprivation of Citizenship, http://www.ilpa.org.uk/resources.php/26059/information-sheet-deprivation-of-citizenship. 44) Ibid.

45) https://www.gov.uk/government/publications/individuals-deprived-of-british-citizenship-since2013/individuals-deprived-of-british-citizenship-since-2013. 
circumstances. When it ratified the Convention in 1966, it explicitly retained the right to deprive on several grounds, including that he 'has conducted himself in a manner seriously prejudicial to the vital interests of her Britannic Majesty. ${ }^{47}$ Despite this formal reservation, the UK later passed the British Nationality Acts 1964 and 1981 which included provisions designed to reduce the problem of statelessness. The latter prohibits citizenship deprivation if the order would make a person stateless. And yet from the outset, it would appear that the UK government's historic commitment to preventing statelessness was tempered by a resolve to retain right to deprive individuals of their citizenship on security grounds.

It is noteworthy that although the UK is no stranger to terrorist threats, earlier governments operating in conditions of emergency, acute security threat and high public concern have not considered it necessary or appropriate to resort to citizenship stripping. Indeed, although it was passed in the immediate aftermath of 9/11, the Nationality, Immigration and Asylum Act 2002 included provisions to ensure that revocation of citizenship would not render an individual stateless. ${ }^{48}$ As the rights organization Liberty observed, 'Even at the height of the war on terror the last Government appeared to recognize that making an individual stateless does not make him a lesser threat. ${ }^{49}$ Similarly, the Immigration, Nationality and Asylum Act 2006, passed in the immediate aftermath of the $7 / 7$ bombings in London, included a prohibition on rendering an individual stateless. ${ }^{50}$

Gibney argues eloquently that the 'constraint against statelessness is not simply a matter of international or domestic law; it is also a normative constraint that stems from basic liberal commitments. Statelessness leaves individuals subject to state power without any of citizenship's basic protections against that power, including security of residence, political rights, and a host of other entitlements. ${ }^{51}$ Instinctively appealing as it may be to expel suspected terrorists and would-be jihadis or to exclude citizens returning from fighting for IS, to do so strikes at the very heart of the state-citizen relationship and the protections it affords. This truth was recognized in the Netherlands, for example, when legislative proposals to permit citizenship revocation of Dutch nationals staying abroad to join terrorist organizations were opposed by the Dutch Council for the Judiciary on the firm ground that revocation could only be applied if it would not result in statelessness. ${ }^{52}$ In sum, historically, the strong constraint

\footnotetext{
47) Immigration Act 2014 Explanatory Notes Commentary on Section 66, http://www.legislation.gov.uk/ukpga/2014/22/notes/division/5/6/2. https://treaties.un.org/pages/ViewDetails.aspx?src=TREATY\&mtdsg no=V-4\&chapter=5\&lang=en\#EndDec.

48) Under S. 4(1)(4), see http://www.legislation.gov.uk/ukpga/2002/41/section/4; M. Gibney (2013) “"A very Transcendental Power": Denaturalisation and the Liberalisation of Citizenship in the United Kingdom', Political Studies 61, pp. 637-655, at 652.

49) Liberty (2014) Liberty's Second Reading Briefing on Clause 60 of the Immigration Bill in the House of Lords, London: Liberty.

50) http://www.legislation.gov.uk/ukpga/2006/13/contents.

${ }^{51)}$ M.J. Gibney (2014) 'Beware states piercing holes into citizenship', Florence: EUDO Observatory on Citizenship, pp. 11-16, http://eudo-citizenship.eu/commentaries/citizenship-forum/1268-thereturn-of-banishment-do-the-new-denationalisation-policies-weaken-citizenship.

${ }^{52)} \mathrm{http}: / / \mathrm{www}$.everaert.nl/en/news/58-nieuws-nationaliteit-en/405-legislative-proposal-for-revocation-of-dutch-citizenship-to-be-detailed.
} 
against statelessness has restricted citizenship revocation to those who hold dual nationality and this restraint has proven an important limit on its use as a tool of counterterrorism.

\section{Denaturalization Under the Immigration Act 2014}

The decision of the UK government to introduce legislation permitting deprivation of citizenship even when to do so results in statelessness is, therefore, a significant departure. Despite the UK's historic avowed commitment to prevent and reduce statelessness, s. 66 of the Immigration Act 2014 significantly increases the risk of rendering denaturalized citizens stateless. It does so by amending s. 40 of the British Nationality Act 1981 (deprivation of citizenship) to provide that where an individual's citizenship status derives from naturalization as a British citizen, the Home Secretary may revoke citizenship if the individual is deemed to have 'conducted him or herself in manner which is seriously prejudicial to the vital interests of the United Kingdom'. ${ }^{53}$ 'Denaturalization' can be ordered provided that i) citizenship was acquired as a result of naturalization and ii) the Home Secretary is satisfied that the deprivation is 'conducive to the public good'. ${ }^{54}$ What is meant by 'conducted him or herself in manner which is seriously prejudicial' is not defined in the Act, though the official Explanatory Notes suggest that serious cases may include 'those involving national security, terrorism, espionage or taking up arms against British or allied forces'. ${ }^{55}$ The decision to revoke citizenship may be made in secret if the government considers it necessary on grounds of national security or public interest. ${ }^{56}$ Moreover, the order can be applied retroactively as s. 66(2) permits the Home Secretary to 'take account of the manner in which a person conducted him or herself before this section came into force'. This is an executive power that can be exercised without prior judicial approval; that is to say, loss of citizenship can be challenged only after the order has been made. Right of appeal is provided for under the British Nationality Act 1981. However, where the Secretary of State certifies that her decision was taken wholly or partly in reliance on information which she considers should not be made public in the interest of national security, the UK's relations with another country or otherwise in the public interest, the right of appeal is to the Special Immigration Appeals Commission (SIAC). Appeals to SIAC must be made within 28 days of the order. ${ }^{57}$

Some protection is provided by the fact that the Act requires that, on making the order, the Home Secretary must have 'reasonable grounds for believing that the person is able to become a national of another country'. Yet, despite this stipulation, there is no legal requirement for the individual to have acquired or been promised citizenship

\footnotetext{
53) http://www.legislation.gov.uk/ukpga/2014/22/section/66/enacted.

54) Ibid.

55) Immigration Act 2014 Explanatory Notes Commentary on Section 66, http://www.legislation.gov.uk/ukpga/2014/22/notes/division/5/6/2.

56) H. Stauffer (2014) 'Steps toward Statelessness', LSE Human Rights Blog, http://blogs.lse.ac.uk/humanrights/2014/08/01/steps-towards-statelessness/.

57) Al Jedda is the only person known to have succeeded in making such an appeal. Ibid. at 322.
} 
of another country before denaturalisation is ordered, nor is there any requirement of timely acquisition. S. 66 thus makes it legally permissible to order denaturalization of naturalized citizens 'regardless of whether or not it will render them stateless'.58

Given the difficulty of deporting those without papers, it seems likely that the UK will use the provision chiefly against those who are already overseas whose ability to mount a successful appeal may therefore be limited. ${ }^{59}$ As Hooper observes, 'As executive discretion has expanded, legal protections have in turn weakened. Challenges relating to the impracticalities from appealing against denaturalisation or exclusion decisions taken whilst the suspect was abroad have already been rejected by the courts. ${ }^{60}$ For those who are denaturalized within the UK, it is unclear what the consequences will be, although in answer to questions in Parliament, the Home Secretary made it clear that 'their status would not attract the privileges of a British citizen', 61 which may refer to the denial of their right of access to social security benefits and public services.

This highly contentious reform arises primarily as a result of the decision of the UK Supreme Court in the case Al-Jedda. ${ }^{62}$ Al-Jedda, a naturalized citizen, had been interned in Iraq by the British authorities for three years on suspicion that he belonged to a terrorist organization. The UK later sought to deprive Al-Jedda of his British citizenship, based on the claim that he could apply to regain his Iraqi citizenship. The government appeal was rejected by the Supreme Court on the grounds that the issue of statelessness was to be determined at the point at which citizenship was deprived and that it was unlawful to render an individual stateless under any circumstances. The Court emphasized that 'worldwide legal disabilities with terrible consequences still flow from lack of nationality'. ${ }^{63}$ In responding to this judgment, the UK government determined that changes brought in by the Nationality, Immigration and Asylum Act 2002 and the Immigration, Asylum and Nationality Act 2006 went further than were required by international law and were passed in anticipation that the UK would sign the European Convention on Nationality 1997, which, in fact, it never did. ${ }^{64}$ The Government claim, therefore, was that s. 66 of the Immigration Act 2014 simply restored the pre-2002 law, that is the commitment the UK had made on signing the UN Convention on the Reduction of Statelessness 1961, which included a retained right to

\footnotetext{
58) Immigration Act 2014 Explanatory Notes Commentary on Section 66, http://www.legislation.gov.uk/ukpga/2014/22/notes/division/5/6/2.

59) Of 17 cases of citizenship deprivation by UK authorities examined by the Bureau of Investigative Journalism, 15 were found to have occurred when the individual was overseas. A. Ross (2014) 'Deprivation of Citizenship: What Do We Know?', Immigration, Asylum and Nationality Law 28(4), pp. 316-325, at 320 .

60) H.J. Hooper (2015) The Counter Terrorism and Security Bill: A Potential Further Erosion of Citizenship Rights in the United Kingdom, Stockholm: Constitutionnet, http://www.constitutionnet.org/news/counter-terrorism-and-security-bill-potential-further-erosion-citizenship-rights-unitedkingdom.

61) House of Lords Library Note on the Immigration Bill (2014) 9, http://researchbriefings.files.parliament.uk/documents/LLN-2014-004/LLN-2014-004.pdf.

62) Al-Jedda v SSHD [2013] UKSC 62, at para.22.

63) Al-Jedda $v$ SSHD [2013] UKSC 62, para.12

${ }^{64)}$ House of Lords Library Note on the Immigration Bill (2014) 6-7, http://researchbriefings.files.parliament.uk/documents/LLN-2014-004/LLN-2014-004.pdf
} 
denaturalize naturalized citizens if they had conducted themselves 'in a manner seriously prejudicial to the vital interests' of the nation. In short, under the Immigration Act 2014, the UK has again made it lawful to denaturalize naturalized citizens even where doing so risks rendering them stateless. ${ }^{65}$

\section{Denaturalization - A Critique}

To strip citizenship and thereby render individuals stateless is surely a regressive step. Given that no empirical evidence has been proffered to show that naturalized citizens pose a greater threat to security than do those who are citizens from birth, the provision is arguably also unwarranted and discriminatory. It has the effect of rendering citizenship by naturalization a more conditional and precarious status than citizenship by birth. Let us examine some of the main grounds for critique.

Conduct that is 'seriously prejudicial to the vital interests of the United Kingdom' self-evidently threatens the public interest and might better be considered an appropriate target for prosecution. Although there is no principle of compulsory prosecution in the UK, ${ }^{66}$ it can, nonetheless, be argued that where the conduct in question seriously infringes the criminal law, it is the role of the state to prosecute and to punish those convicted. Simply to strip individuals of citizenship in order to deport them from the territory or to prohibit their return arguably constitutes a failure of responsibility by the state to prosecute those who contravene the criminal law. Moreover, the Immigration Act 2014 permits the stripping of citizenship by executive order without any requirement of open proceedings in which the case for denaturalization can be challenged or rebutted. S. 66 thus places considerable power in the hands of the executive to strip citizenship, even when it is ordered against the advice of the security services. ${ }^{67}$ Furthermore, by stipulating that, 'the Secretary of State may take account of the manner in which a person conducted him or herself before this section came into force', $\mathrm{s}$. 66(2) contravenes the fundamental legal principle against retroactivity, namely that one should only be held liable for conduct that was unlawful at the time of its commission.

Although s. 66 of the Immigration Act 2014 includes a requirement periodically to review the operation of this deprivation power, this is hardly a sufficient safeguard. It is unlikely to be of much comfort or assistance to those who have already been rendered stateless, particularly since a deprivation order can be made without a public hearing and with immediate effect, and not, as one might expect, after all rights of

${ }^{65)}$ ILPA (2014) Information Sheet - Immigration Act 2015: Deprivation of Citizenship, London: ILPA, http://www.ilpa.org.uk/resources.php/30368/information-sheet-immigration-act-2014-deprivation-of-citizenship.

66) Akin to the German Legalitätsprinzip (principle of legality). See M.D. Dubber (2010) The Legality Principle in American and German Criminal Law: An Essay in Comparative Legal History, http://dx.doi.org/10.2139/ssrn.1735966 13.

67) A. Ross (2014) 'Deprivation of Citizenship: What Do We Know?', Journal of Immigration Asylum and Nationality Law 28(4), pp. 316-325, at 320-321, http://sprc.info/wp-content/uploads/2015/02/Ross-article.pdf. 
appeal have been exhausted. ${ }^{68}$ The very narrow timeframe of 28 days in which to lodge the appeal, the problem of securing legal advice and of furnishing supporting documents, particularly if the individual is in a country where communication is poor, all compound the difficulties of bringing a successful appeal. Where the grounds for appeal rely upon security sensitive material, the power of the Special Immigration Appeals Commission (SIAC) to resort to closed material proceedings further limits the ability of the appellant to challenge their case effectively.

The state has a duty to provide security for its citizens so it cannot be that citizenship deprivation simply permits the state to disregard the consequences for those so deprived, particularly where the effect is to render them stateless. Without the diplomatic protections and consular services conveyed by a passport, the stateless are extremely vulnerable to abuse. Of the sixteen British nationals who have had their passports revoked while abroad or who were since deported by the UK government since 2010, at least two have since been killed by US drone strikes, one kidnapped and another subject to rendition by US security services. ${ }^{69}$ In 1958, Chief Justice Warren of the US Supreme Court argued that use of denationalization 'is a form of punishment more primitive than torture'. ${ }^{70}$ While it is debatable whether or not it is appropriate to characterize denaturalization as punishment, this powerful condemnation of the power to render individuals stateless is no less pertinent today.

There are also issues of international law: states admit individual passport holders in good faith that they are entitled to return - the principle of 'returnability'. ${ }^{71}$ If the UK government were to exercise the power to denaturalise an individual while overseas this would breach the UK's obligation to the admitting state to permit that individual to return home. According to Goodwin-Gill, such a state would, 'be fully entitled to ignore any purported deprivation of citizenship and, as a matter of right, to return that person to the United Kingdom. ${ }^{72}$ The admitting state would otherwise be left in the unhappy position of being unable to rid themselves of individuals (deemed by the UK to pose a grave threat to security) who would be effectively marooned on their territory.

There are also serious questions to be asked about the rights engaged by the power to denaturalize. As signatory to the ECHR, the UK has an obligation to uphold Convention rights, not least through the engine of pre-legislative scrutiny. The UK government considered but rejected the possibility that denaturalization might be discriminatory under Article 14 ECHR, declaring itself satisfied there was 'an objective and

${ }^{68)}$ A. Harvey (2014) 'Recent Developments on Deprivation of Nationality on Grounds of National Security and Terrorism Resulting in Statelessness', Journal of Immigration Asylum and Nationality Law 28(4), pp. 336-354, at 340.

69) https://www.thebureauinvestigates.com/category/projects/deprivation-citizenship/.

70) HL Report, 17 March 2014, col 53, the debate refers Warren's judgment in Trop v Dulles (1958) 356 U.S. 86.

${ }^{71)}$ G.S. Goodwin-Gill (2014) Deprivation of Citizenship, Statelessness and International Law: More Authority (if it were needed...), at p. 1, https://s3.amazonaws.com/s3.documentcloud.org/documents/1154592/gsgg-deprivationcitizenship-moreauthority.pdf.

${ }^{72)}$ G.S. Goodwin-Gill (2014) Deprivation of Citizenship resulting in Statelessness and its Implications in International Law Opinion, at pp. 11-12, https://assets.documentcloud.org/documents/1086878/guy-s-goodwin-gill-legal-opinion-on-deprivation.pdf. 
reasonable justification for treating naturalized citizens differently from others' on the grounds that, 'Naturalised citizens have chosen British values and have been granted citizenship on the basis of their good character. It is therefore appropriate to restrict a measure with such serious consequences as becoming stateless to naturalised citizens. ${ }^{73}$ The government's position appears to rest on the quasi-contractarian notion that naturalization depends on a contractual agreement between state and foreigner, by which the state offers the individual the right to be treated as a citizen on the precondition that they promise to be loyal to the state and abide to its laws. On this account, naturalized citizens, who act 'in manner which is seriously prejudicial to the vital interests' of the receiving state, violate their duty of loyalty and show themselves to be undeserving of citizenship. And it is on this basis that the contract of acquired citizenship may be dissolved through denaturalization. On the other hand, it arguable that to set higher expectations is to render naturalized citizenship conditional on standards of behaviour not demanded of natural born citizens. To do so thus creates a category of second class citizens; whereas, it should be noted, the 1961 UN Convention on Statelessness does not differentiate between categories of citizenship. Moreover, since s. 66 is justified on security grounds, in the absence of any evidence that naturalised citizens pose a greater threat than birth citizens, it is indefensible to discriminate against them in this way.

To the claim that the s. 66 power to render an individual stateless is capable of engaging the Article 8 ECHR right to private life, ${ }^{74}$ the UK Home Office has retorted that insofar as 'nationality is part of a person's identity and, therefore, potentially their private life', all citizenship deprivation is capable of engaging Article 8, not only that which renders an individual stateless. ${ }^{75}$ The UK government may be able to invoke the exception on the face of Article 8(2) that the interference in private and family life is lawful provided it can be shown to be "necessary in a democratic society in the interests of national security, public safety or the economic well-being of the country, for the prevention of disorder or crime'. ${ }^{76}$ It is, however, questionable whether in cases concerning 'economic well-being' the grave loss of security entailed by citizenship deprivation can ever be deemed proportionate.

During the passage of the Immigration Bill, the UK government made the dubious claim that 'where an individual is not in the UK's jurisdiction for the purposes of the ECHR, that person's Article 8 rights will not be engaged by a deprivation' ${ }^{77}$ A similar claim was made in respect of Articles 2 and 3 (right to life and prohibition against torture and inhuman or degrading treatment or punishment), namely that if an individual is on the territory of another state denaturalization does not engage Convention

\footnotetext{
73) See discussion in Human Rights Joint Committee, Legislative Scrutiny: Immigration Bill (Second Report), S. 50, http://www.publications.parliament.uk/pa/jt201314/jtselect/jtrights/142/14205.htm.

74) See e.g. Genovese v Malta (Application no. 53124/09, 11 November 2011).

${ }^{75)}$ Home Office (2014) Immigration Bill - European Convention on Human Rights Supplementary Memorandum, London, https://www.gov.uk/government/.../Deprivation_ECHR_memo.pdf.

76) Ibid., p. 3.

77) Ibid., p. 4. Although it did acknowledge that where the individual's family remained in the UK, citizenship deprivation could have an impact on the Article 8 rights of the family.
} 
rights because they are outside the UK's jurisdiction. ${ }^{78}$ These claims were firmly rebutted by the UK Parliament's Joint Committee on Human Rights, which argued 'In our view, a deprivation decision must be compatible with those Articles whether the citizen concerned is abroad or in the UK at the time of the deprivation decision. ${ }^{79}$ The Committee drew on Goodwin-Gill's observation that it is 'wishful legal thinking to suppose that a person's ECHR rights can be annihilated simply by depriving that person of citizenship while he or she is abroad ... the act of deprivation only has meaning if it is directed at someone who is within the jurisdiction of the State. A citizen is manifestly someone subject to and within the jurisdiction of the State, and the purported act of deprivation is intended precisely to affect his or her rights ${ }^{80}{ }^{80}$ In short, the act of withdrawing nationality is itself an exercise of jurisdiction and therefore Convention rights are necessarily engaged.

From the critique of rights erosions, let us turn to the question of efficacy. Strategies of denaturalization, citizenship deprivation and deportation rely on the questionable supposition that they do in fact serve to increase security. The rights organization Liberty describe this as 'the security fallacy' and suggest that it is naïve to believe that 'in this shrinking interconnected world, that crude medieval punishment of banishment or exile will produce any security gains. ${ }^{81}$ To the contrary, denaturalization renders individuals vulnerable and more susceptible to recruitment by terrorist organizations, particularly if the result is to strand them in unstable states or conflict zones. Yet the commitment to deport terror suspects persists. This is so despite the fact that the risks of so doing were recognized as early as 2003 by the UK Newton Committee, which concluded: 'Seeking to deport terrorist suspects does not seem to us to be a satisfactory response, given the risk of exporting terrorism ... it would not necessarily reduce the threat to British interests abroad, or make the world a safer place more generally. ${ }^{, 82}$ Given the Committee's perceptive conclusion that the practice may amount to no more than 'exporting terrorism', it is remarkable that faith in this strategy persists unchallenged. ${ }^{83}$

In the case that terror suspects are denaturalized while at home, the effect will be to leave them without travel documents, yet the threat they pose is scarcely diminished. The ability to plot, finance and orchestrate terrorist atrocities may not be reduced whether the individual is denaturalized at home or abroad. Insofar as denaturalization

\footnotetext{
${ }^{78)}$ On the grounds that 'If an individual were not within its jurisdiction for the purposes of the ECHR, then deprivation could not breach the individual's Article 2 or 3 rights because those rights would not be engaged.' Ibid., p. 5.

79) Joint Committee on Human Rights (2014) Legislative Scrutiny: Immigration Bill (second report), HL paper 142/HC paper 1120, http://www.parliament.uk/business/committees/committees-az/joint-select/human-rights-committee/news/report-on-immigration-bill/ p.4.

${ }^{80)}$ Ibid., p. 16.

${ }^{81)}$ Liberty (2014) Liberty's Second Reading Briefing on Clause 60 of the Immigration Bill in the House of Lords, London: Liberty.

${ }^{82)}$ Privy Council Review Committee, Anti-terrorism, Crime and Security Act Review 2001: Report quoted in C. Walker (2007) 'The Treatment of Foreign Terror Suspects', Modern Law Review 70(3), pp. 427-57, at 433.

${ }^{83)}$ Note that a very different view prevails in the United States see e.g. P.J. Spiro (2014) 'Expatriating Terrorists', Fordham Law Review 82, pp. 2169-2187.
} 
is regarded as unjust and discriminatory, it may even prove counterproductive, especially if it generates disaffection among target populations, their families and communities. Far from improving security, it may feed the conditions of exclusion, alienation and hostility that are conducive to radicalization. In sum, citizenship stripping as a tool of security would appear to be a dubious device fraught with grave risks but of no proven efficacy.

\section{Conclusion}

The very raison d'être of the modern state is to exercise its sovereign power to provide conditions of security and good order within its dominion for its citizens. ${ }^{84}$ The global threat of serious crime and terrorism has prompted states to ever greater efforts to police mobility and strengthen their borders. The imperative to disrupt the movement and activities of those deemed to pose a terrorist threat targets the mobility of would-be terrorists and foreign fighters and it increases the importance of border security. No surprise here. Border control is the first line of national defence and the right to exclude noncitizens is 'the ultimate prerogative of sovereignty'. ${ }^{85}$

Resort to immigration law has been driven partly by the questionable claim that foreigners pose the greater threat and partly by the even more contentious underlying assumption that noncitizens, naturalized and even dual citizens do not and should enjoy the same legal protections as citizens. ${ }^{86}$ Their status is conditional, their loyalty apparently suspect, and their enjoyment of the 'privileges' of citizenship made dependent upon good conduct. A common feature of immigration law as a tool of counterterrorism is that it targets precisely those who, because their status is already precarious, are most easily subject to draconian and discriminatory laws. It suggests an instrumental resort to immigration law to target non-citizens, naturalized and dual citizens in ways that are not possible in respect of sole, born citizens. Yet human rights should provide safeguards for persons by virtue of their status as humans and out of respect for their humanity, regardless of whether or not they are citizens and regardless of what category of citizenship they may hold. ${ }^{87}$

The United Kingdom's powers to revoke the citizenship of dual nationals if suspected or convicted of terrorist-related activity already made it an outlier among western countries. Its decision to provide for the stripping of citizenship of naturalized citizens, who have no second nationality and who will, as a result, be stateless, is a very

${ }^{84)}$ L. Lazarus (2007) 'Mapping the Right to Security', in: B. Goold \& L. Lazarus (eds.), Security and Human Rights, Oxford,: Hart Publishing, pp. 325-346.

${ }^{85)}$ Macklin, 'Borderline Security', op.cit., n. 19, p. 389.

86) L. Jarvis \& M. Lister (2015) Anti-Terrorism, Citizenship and Security, Manchester: Manchester University Press, Ch. 2. 'Citizenship and Security'; S. Lavi (2011) 'Citizenship Revocation as Punishment: On the modern duties of citizens and their criminal breach', University of Toronto Law Journal 61, pp. 783-810.

${ }^{87)}$ Article 6, for example, guarantees a right to a fair trial that should apply no less to the foreigner and to the stateless person. See e.g. C. Walker (2007). 'The Treatment of Foreign Terror Suspects', Modern Law Review, 70(3), pp. 427-457, at 443 ff; D. Cole (2007) 'Against Citizenship as a Predicate for Basic Rights', Fordham Law Review 75, pp. 2541-2548. 
substantial expansion of that power. Denaturalization that results in stateless would appear to create a legal black hole into which, once people fall, they cannot easily be extracted. The power to deprive naturalized citizens of their citizenship even if it renders them stateless may not, in law, breach the UK's obligations under the 1961 UN Convention on Statelessness. It is, however, a significant and regrettable undermining of UK's historic commitment to reducing statelessness and to upholding human rights. The declared purpose of denaturalization is to deny citizenship to individuals deemed to be a risk to national security. However, it is questionable whether in practice it serves to do so since, as we have observed, contemporary terrorist networks operate globally, virtually and across borders. ${ }^{88}$ What remains beyond question, however, is that denaturalization radically undermines the security of citizenship by discriminating against certain classes of citizen; by rendering the status of dual and naturalized citizens more precarious; and by enabling citizenship to be stripped even where it results in the most insecure condition of all - statelessness.

${ }^{88)}$ R. Bauböck \& S. Paskalev (2015) Citizenship Deprivation: A Normative Analysis, CEPS Paper in Liberty and Security in Europe 82, Brussels: CEPS, pp. 1-37, at 16, http://www.ceps.eu/publications/citizenship-deprivation-normative-analysis. 